\title{
Multiple Paleozoic magmatic-orogenic events in the Central Extremadura batholith (Iberian Variscan belt, Spain)
}

\author{
M. Francisco Pereira ${ }^{1} \cdot$ Antonio Castro ${ }^{2} \cdot$ Carlos Fernández ${ }^{2} \cdot$ Carmen $_{\text {Rodríguez }}$ An $^{3}$
}

Received: 27 November 2017 / Accepted: 6 April 2018 / Published online: 23 April 2018

(c) Springer International Publishing AG, part of Springer Nature 2018

\begin{abstract}
Background The Central Extremadura batholith located in the southeast part of the Central Iberian Zone (e.g. Iberian Autochthonous domain of the Iberian Variscan belt) was originally thought to have been generated entirely during Carboniferous igneous activity. However, some recent geochronological work has shown the existence of Ordovician plutonic rocks. Purpose The aim of this study is to re-examine the age of granitic rocks in the Central Extremadura batholith and complement this information with new field and geochemical data. This data set is used: to constrain the relative timing of plutons emplacement, as well as deformation and metamorphism preserved in the host rocks; to track deep crustal rocks and granitic magma sources; and to discuss prevailing tectonic evolutionary models for the Paleozoic evolution of the Iberian Variscan belt.

Methods We use geochemical and SHRIMP U-Pb zircon geochronology data of three granitic plutons (Ruanes, Plasenzuela and Albalá) from the Central Extremadura batholith to track magmatic sources and provide a better understanding of temporal and spatial relationships between deformation and magmatism in the Iberian Variscan belt.

Results Ruanes tonalite dated at $464 \pm 2 \mathrm{Ma}$ is peraluminous, magnesian and calc-alkaline, as typical of a magmatic arc setting. We report, for the first time, the occurrence of a Middle Ordovician intrusion spatially and temporally related to host deformed rocks of the Central Iberian Zone (e.g. the Iberian Autochthonous domain), which reached high-grade metamorphic conditions. Plasenzuela two-mica leucogranite is strongly peraluminous and of anatectic origin and includes a Neoproterozoic and Ordovician population of inherited zircon grains. This granite possibly derived from the partial melting of a crustal source composed of Neoproterozoic metapelites and metagreywackes (Schist-Greywacke Complex) and/or Lower Ordovician gneisses (Ollo de Sapo Formation), both including greywackes of volcano-sedimentary origin and peraluminous composition. The crystallization age of $330 \pm 7 \mathrm{Ma}$ obtained for the syn-kinematic Plasenzuela two-mica leucogranite constrains the functioning of D2 dextral strike-slip shear zones within the Iberian Autochthonous domain. The age of $309 \pm 2 \mathrm{Ma}$ obtained for the Albalá cordierite-bearing monzogranite matches the age interval of the calc-alkaline magmatic suite post-dating the main Variscan D1-D3 structures in the Iberian Autochthonous domain.

Conclusion The new data presented in this study make it possible to recognize multiple Paleozoic magmatic-orogenic events (e.g. Caledonian, Variscan and Cimmerian) in the Central Extremadura batholith. During the Ordovician, the emplacement of intermediate magmas at shallow depths gave rise to extensive metamorphism due to heat transfer to the host rocks. The onset of this Ordovician plutonic-metamorphic complex in the Iberian Autochthonous domain is contemporaneous with the development of an active continental margin probably related to the subduction of the Iapetus-Tornquist Ocean (i.e. the Caledonian orogeny). During the Lower Carboniferous, these D2 strike-slip domains acted as lateral margins of largescale gravitational collapses associated with the SE-direct transport of low-angle extensional shear zones (i.e. the Variscan cycle). The emplacement of Upper Carboniferous arc type granitic rocks is interpreted in the context of the amalgamation of Pangaea and the spatial proximity of Iberia relative to the Eurasian active margin in the course of Paleotethys subduction (i.e. the Cimmerian orogeny).
\end{abstract}

Electronic supplementary material The online version of this article (https://doi.org/10.1007/s41513-018-0063-5) contains supplementary material, which is available to authorized users.

Extended author information available on the last page of the article 